\title{
Neurite Degeneration Induced by Heme Deficiency Mediated via Inhibition of NMDA Receptor-Dependent Extracellular Signal-Regulated Kinase 1/2 Activation
}

\author{
Tatyana Chernova, Joern R. Steinert, Christopher J. Guerin, Pierluigi Nicotera, Ian D. Forsythe, and Andrew G. Smith \\ Medical Research Council Toxicology Unit, Hodgkin Building, University of Leicester, Leicester LE1 9HN, United Kingdom
}

\begin{abstract}
The early stages of many neurodegenerative diseases and age-related degeneration are characterized by neurite damage and compromised synaptic function that precede neuronal cell death. We investigated the signaling mechanisms underlying neurite degeneration using cortical neuron cultures. Inhibition of heme synthesis caused neurite damage, without neuronal death, and was mediated by reduced NMDA receptor (NMDAR) expression and phosphorylation. The signaling toward the degenerative phenotype involved suppression of the extracellular signal-regulated kinase 1/2 (ERK1/2) pathway, and electrophysiological recording showed that the neurodegeneration is accompanied by reduced NMDAR current and $\mathrm{Ca}^{2+}$ influx, as well as reduced voltage-gated sodium currents, consistent with compromised neurite integrity. Rescue from the degenerative phenotype by heme replacement was dependent on restoration of NR2B subunit phosphorylation and expression of NMDAR currents with higher $\mathrm{Ca}^{2+}$ permeability, consistent with triggering prosurvival ERK1/2 signaling to maintain and extend neurites. This study demonstrated a new mechanism of neurodegeneration in which impaired heme synthesis led to NMDAR signaling dysfunction, suppression of the prosurvival ERK1/2 pathway, and progressive fragmentation of neuronal projections.
\end{abstract}

Key words: neurodegeneration; heme; ERK pathway; NMDA receptor; patch clamp; neuron

\section{Introduction}

The early pathological finding of neurodegenerative diseases is a selective loss of synaptic connections in the absence of cell soma demise (Fiala et al., 2002). Many neurodegenerative disorders are age-related and characterized by progressive cognitive or motor impairment. Mitochondrial dysfunction leading to oxidative damage is thought to be a major contributor to brain aging and injury and occurs at an early stage of all major age-related neurodegenerative diseases (Liu and Ames, 2005). Heme is an essential component of mitochondria, and initial and late stages of its synthesis also occur in the organelle. Thus, disturbed heme metabolism could precede impaired cytochrome activity. Heme synthesis declines with age in rodents (Bitar and Shapiro, 1987), and deficiency of heme has been proposed as a factor in aging and in Alzheimer's disease (Atamna et al., 2002). In both neurodegenerative disorders and normal aging, heme deficiency may be compounded by its enhanced turnover via induced heme oxygenase 1 (HMOX1) (Schipper, 2000; Perry et al., 2003).

The importance of heme in mammalian neurobiology, however, extends beyond its functions as a direct constituent of mitochondrial cytochromes to being a prosthetic group in a large number of proteins in oxygen sensing and metabolism, detoxifi-

Received Feb. 21, 2007; revised June 8, 2007; accepted June 11, 2007 We thank the members of the Biomedical Services staff for their assistance.

Correspondence should be addressed to Tatyana Chernova, Medical Research Council Toxicology Unit, Hodgkin Building, University of Leicester, Lancaster Road, Leicester LE1 9HN, UK. E-mail: tc28@le.ac.uk. DOI:10.1523/JNEUROSCI.0792-07.2007

Copyright $\odot 2007$ Society for Neuroscience $\quad$ 0270-6474/07/278475-11\$15.00/0 cation, control of oxidative damage, growth and differentiation, and production of CO and nitric oxide (Padmanaban et al., 1989; Jover et al., 2000; Meyer et al., 2005). A small proportion of heme forms a regulatory pool that can act in a signaling mode by binding to heme-regulatory motifs in a number of proteins, including BK ion channels (Tang et al., 2003), transcription factors such as NPAS2 (neuronal PAS domain protein 2) and Bach1 (BTB and CNC homology 1) (Ogawa et al., 2001; Dioum et al., 2002), and circadian clock and receptor-associated proteins (Kaasik and Lee, 2004; Ghosh et al., 2005). Heme is involved in processing of microRNAs that regulate the expression of many genes (Faller et al., 2007). Exogenous heme promotes neurite outgrowth in neuroblastoma cells (Ishii and Maniatis, 1978), whereas in nerve growth factor (NGF)-induced PC12 cells, depletion of heme causes inactivation of the prosurvival Ras-extracellular signalregulated kinase (ERK) cascade and activation of the proapoptotic c-Jun N-terminal protein kinase (JNK) pathway (Zhu et al., 2002; Sengupta et al., 2005). Activation of the major prosurvival ERK1/2 pathway is coupled to $\mathrm{Ca}^{2+}$ influx through the NMDA receptor (NMDAR) (Bading and Greenberg, 1991), and the physiological patterns of synaptic NMDAR activity are strongly neuroprotective (Lipton and Nakanishi, 1999; Hardingham et al., 2002; Tashiro et al., 2006). Therefore, heme deficiency could be linked to neurite damage and eventual cell death. Cultured hemedeficient cortical neurons show progressive senescence and downregulation of neuron-specific genes, including NMDAR (Chernova et al., 2006).

Here we show that heme deficiency in cultured cortical neu- 
rons leads to a neurodegenerative phenotype with neurite fragmentation, combined with reduced NMDAR-mediated and voltage-gated sodium currents. The neuronal damage and the reversal of neurodegeneration by heme replacement are mediated via the NMDAR-dependent ERK1/2 pathway. These findings suggest that heme may act as a signaling molecule to maintain neurite integrity.

\section{Materials and Methods}

Primary cell culture. Primary cortical neurons were isolated from 14-d-old fetuses of the $\mathrm{BALB} / \mathrm{c}$ mouse strain bred in house. The BALB/c Fech ${ }^{\text {mlPas }}$ mouse strain was obtained from the The Jackson Laboratory (Bar Harbor, ME). The Fech ${ }^{\text {mlPas }}$ mutant contains a point mutation in the ferrochelatase gene (Tutois et al., 1991; Davies et al., 2005). Mice were bred by homozygous mating and maintained in a negative pressure isolator at $21^{\circ} \mathrm{C}$ under reduced light to prevent skin lesions. Isolated brain cortex of embryos was gently dissociated, and the cells were washed twice in Neurobasal medium (Invitrogen, Paisley, UK) supplemented with $10 \%$ fetal calf serum. Cell suspensions were plated on poly-L-lysine-coated $35 \mathrm{~mm}$ plates at a density of 2 million cells per dish as described previously (Sangerman et al., 2001). After attachment of the cells, the plating medium was changed to culture medium containing 96\% (v/v) Neurobasal medium (Invitrogen), 2 mm glutamax, 2\% B-27 supplement (Invitrogen), $100 \mu \mathrm{g} / \mathrm{ml}$ streptomycin, and $100 \mathrm{U} / \mathrm{ml}$ penicillin. Viability of the cells was estimated by the trypan blue exclusion assay and was $>80 \%$. After $5 \mathrm{~d}$, the culture was treated with $10 \mu \mathrm{M}$ cytosine arabinoside for $3 \mathrm{~d}$ to stop proliferation of glial cells or fibroblasts. The cells were grown in a humidified incubator at $37^{\circ} \mathrm{C}(95 \%$ room air, $5 \% \mathrm{CO}_{2}$ ).

Inhibition and measurement of heme synthesis. To inhibit heme synthesis, cells were cultured in serum-free medium with $0.5 \mathrm{~mm}$ succinyl acetone (SA) (Sigma, Dorset, UK) continuously for the duration of the experiments. For measurement of heme synthesis, cells were incubated with $0.4 \mu \mathrm{Ci}$ of $\left[3,5-{ }^{3} \mathrm{H}\right]$ aminolevulinic acid hydrochloride (ALA; $2.6 \mathrm{Ci} / \mathrm{mmol}$; PerkinElmer, Boston, MA) for $24 \mathrm{~h}$. Heme was extracted from the cells by acetone- $\mathrm{HCl}$ and diethyl ether. The amount of radioactivity in extracted heme was measured by scintillation counting as described previously (Shedlofsky et al., 1987). Total recovery of radioactivity from all fractions was the same for treated and untreated cells. For heme readmission experiments, cells were treated daily with $100 \mathrm{~nm}$ hemin; stock solution was added to human serum albumin in a 1:1 molar ratio before treatment (Taketani et al., 1998). The heme concentrations were spectrophotometrically verified.

Viability assay. Cell viability in heme depletion experiments was estimated by using the LIVE/DEAD Reduced Biohazard Viability/Cytotoxicity kit (Invitrogen) according to the instructions of the manufacturer. The amounts of live and dead cells were scored with a fluorescence microscope .

RNA extraction and quantitative real-time PCR analysis. Treated and untreated cells at different time points were collected, and total RNA was isolated by using TRI-reagent (Sigma). cDNA synthesis was performed using random primers and Superscript II (Invitrogen). PCR primers were selected using the Primer Express version 2.0 Software program
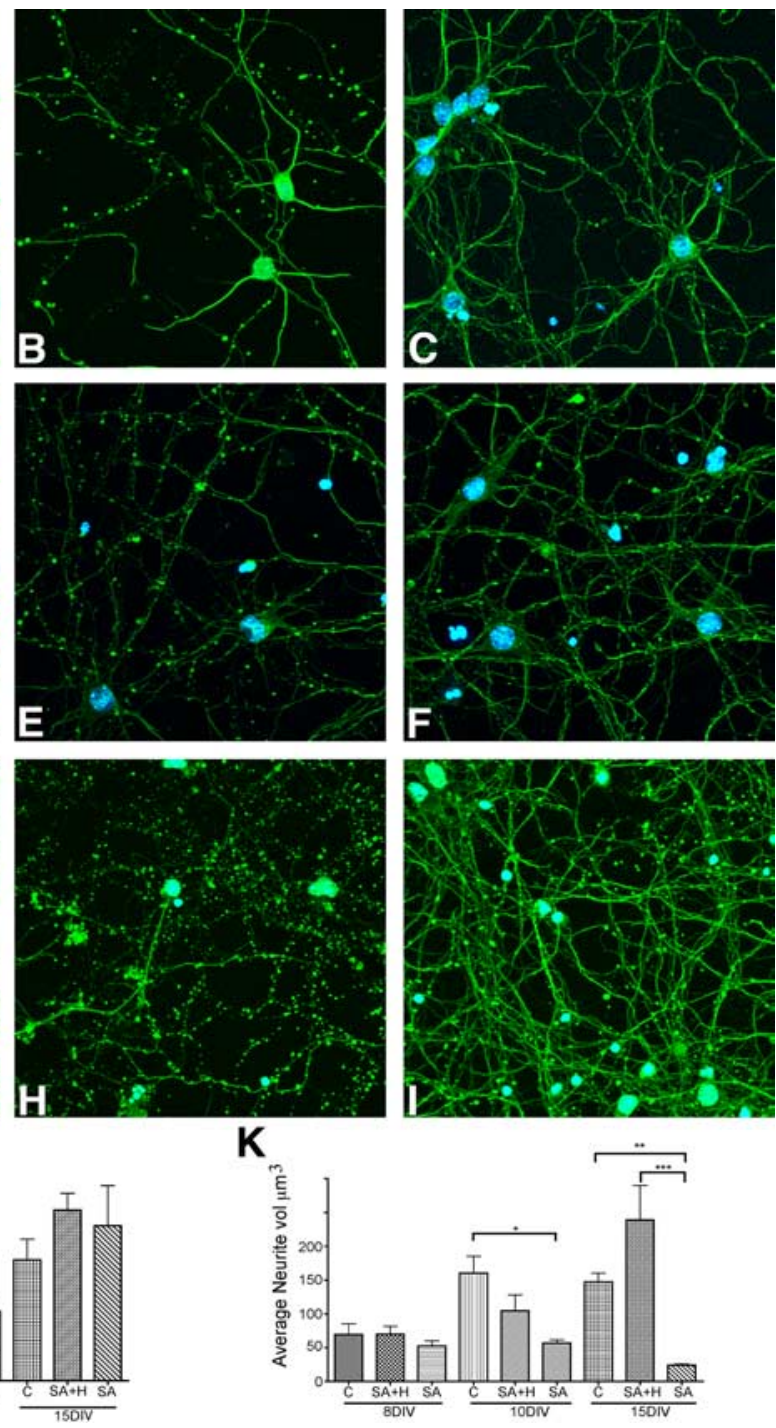

Figure 1. Neurodegeneration of cultured cortical neurons caused by heme deficiency. Confocal micrographs of maximum treated with $S A ; C, F, I$, cells treated with $S A$ and heme $(H)$. Quantification of immunostaining for $\beta$ III-tubulin reflecting the degree of neurodegeneration. $\boldsymbol{K}$, Average neurite volume in control and treated cultures at each time point. $\boldsymbol{J}$, Total volume per nuclei in image fields examined. ${ }^{*} p<0.05 ;{ }^{* *} p<0.01 ;{ }^{* * *} p<0.001$.

(Applied Biosystems, Foster City, CA). Primers sequences were as follows: $\beta$-actin forward primer, $5^{\prime}$-GATTACTGCTCTGGCTCCTAGCA3'; $\beta$-actin reverse primer, 5'-GTGGACAGTGAGGCCAGGAT-3'; $\delta$-aminolevulinate synthase 1 (ALAS1) forward primer, $5^{\prime}$-TCTTCCGCAAGGCCAGTCT-3', ALAS1 reverse primer, 5' -TGGGCTTGAGCAGCCTCTT-3'; HMOX1 forward primer, 5' -CACTTCGTCAGAGGCCTGCTA- $3^{\prime}$; HMOX1 reverse primer, $5^{\prime}$-GTCTGGGATGAGCTAGTGCTGAT-3'; NMDA NR2B forward primer, 5' -CTTAATCTGTCCGCCTAGAGCTTT-3'; and NMDA NR2B reverse $5^{\prime}$-TGCGCTGGGCTTCATCTT-3'.

Primers were designed to cross exon-exon boundaries, and the concentration was optimized (300-900 nM) to ensure that the efficiency of the target amplification and the efficiency of the endogenous reference amplification are approximately equal. PCR was performed using SYBR Green PCR Master Mix, primers, and 10 ng of reverse-transcribed cDNA in the ABI PRISM 7700 Sequence Detection System (Applied Biosystems); the thermal cycler protocol was as follows: stage one, $50^{\circ} \mathrm{C}$ for 2 min; stage two, $95^{\circ} \mathrm{C}$ for $10 \mathrm{~min}$; stage three, 40 cycles at $95^{\circ} \mathrm{C}$ for $15 \mathrm{~s}$ and $60^{\circ} \mathrm{C}$ for $1 \mathrm{~min}$. Each sample was run in triplicate. Quantification was performed using the comparative CT method $(\Delta \Delta \mathrm{CT})$. Data are pre- 
A

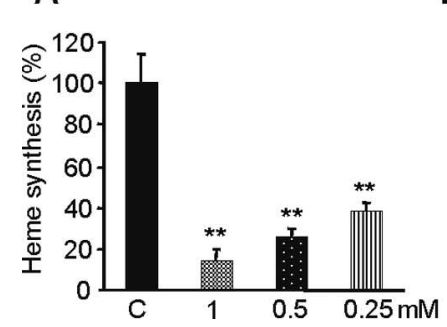

B

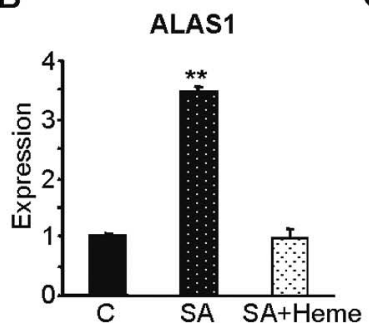

C

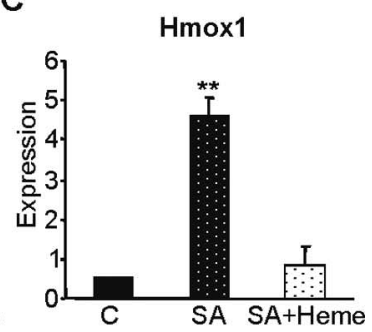

Figure 2. Inhibition of heme synthesis in primary cortical neurons. Neurons were cultured in the presence of $1,0.5$, or $0.25 \mathrm{~mm}$ SA for $14 \mathrm{~d}$. $A$, Treated with SA and control (C) cells were incubated with [ $\left.{ }^{3} \mathrm{H}\right] \mathrm{ALA}$ for $24 \mathrm{~h}$ on day 14 , and then labeled heme was extracted and measured $(n=5)$. B, C, Expression of ALAS1 and HMOX1 in control and $0.5 \mathrm{~mm} \mathrm{SA-treated} \mathrm{on} \mathrm{day} 14$ with or without $100 \mathrm{~nm}$ heme cultures, estimated by real-time reverse transcription-PCR. ${ }^{* *} p<0.01$, statistically different from control group.

sented as the mean $\pm \mathrm{SD}$ ( $n=3-8$ for each group). Statistical significance was assessed as $p<0.05$ using one-way ANOVA.

Immunoblotting. Proteins were extracted from primary neurons after 14 and $21 \mathrm{~d}$ of culturing using lysis buffer ( $7 \mathrm{~m}$ urea, $50 \mathrm{~mm}$ Tris- $\mathrm{HCl}$, $\mathrm{pH} 7.5$, and $5 \mathrm{~mm}$ DTT) followed by brief sonication. SDS electrophoresis and immunoblotting were performed (Davies et al., 2005) using enhanced chemiluminescence detection (GE Healthcare, Little Chalfont, UK) and primary antibodies from the following sources: phosphoERK1/2, ERK1/2, phospho-c-Raf (Ser338), phospho-c-Raf (Ser259), phospho-NMDAR1 (Ser 890, Ser 896, and Ser 897), phospho-JNK (T183/185), phospho-p38 mitogen-activated protein kinase (MAPK), phospho-cAMP response element-binding protein (CREB), and total CREB from Cell Signaling Technology (Beverly, MA); NMDA NR1, $\alpha$-tubulin, B-Raf, and phospho-B-Raf from Santa Cruz Biotechnology (Santa Cruz, CA); and NMDA NR2B and phospho-NMDA NR2B from PhosphoSolutions (Aurora, CO). Results were quantified using densitometry and Image Quant 5.2 software. Statistical significance of data were estimated using two-tailed Student's $t$ test.

Immunocytochemistry. After treatment, cells were fixed with $4 \%$ paraformaldehyde at room temperature for $20 \mathrm{~min}$ and permeabilized with $0.2 \%$ Triton X-100 (Sigma) in PBS for 5 min. Cells were then incubated with rabbit anti- $\beta$ III-tubulin (1:3000) antibody (Cell Signaling Technology) at room temperature for $1 \mathrm{~h}$. Secondary antibody (goat anti-rabbit Alexa Fluor 488 at 1:500) were then added for $1 \mathrm{~h}$, followed by nuclear staining with $300 \mathrm{~nm} \mathrm{4'-6-diamidino-2-phenylindole} \mathrm{for} 10 \mathrm{~min}$. Secondary antibodies alone were used as specificity controls and uniformly resulted in very low background levels of fluorescence.

Treatment with inhibitors. Kinase inhibitors were applied to the neurons undergoing various treatments as follows: $10 \mu \mathrm{M}$ U0126 [1,4diamino-2,3-dicyano-1,4-bis(o-aminophenylmercapto)butadiene]

(Calbiochem, La Jolla, CA), $50 \mu \mathrm{M}$ LY294002 [2-(4-morpholinyl)-8phenyl-1(4H)-benzopyran-4-one] (Cell Signaling Technology), $10 \mu \mathrm{M}$ GF109203X (LC Laboratories, Woburn, MA), 100 nm Ro 31-8220 (2-[1(3-(amidinothio)propyl)-1 H-indol-3-yl]-3-(1-methylindol-3-

yl)maleimide) (Sigma), and 50 nм PP2 [4-amino-5-(4-chlorophenyl)-7( $t$-butyl)pyrazolo[3,4- $d$ ] pyrimidine] (Calbiochem) for $30 \mathrm{~min}$. NMDAR competitive antagonist $50 \mu \mathrm{M} \delta$-2-amino-5-phosphonovalerate (APV; Sigma) or NMDAR NR2B subunit-selective antagonist $10 \mu \mathrm{M}$ ifenprodil [ $\alpha$-(4-hydroxphenyl)- $\beta$-methyl-4-benzyl-1-piperidineethanol tartrate] (Sigma) were added to the media of the treated cells for $30 \mathrm{~min}$ before harvesting.

Imaging and quantification of immunostaining. Images of cultured cells were obtained with a Zeiss (Jena, Germany) LSM 510 META confocal microscope equipped with a $25 \times, 0.8$ numerical aperture water immersion lens. Fluorochromes were excited with a pulsed $780 \mathrm{~nm}$ titanium/ sapphire laser (Newport Spectra Physics, Didcot, Oxfordshire, UK). Images were collected as $Z$ series of 12 sections with voxel dimensions of $x, y, z=0.32 \times 0.32 \times 0.32 \mu \mathrm{m}(4 \mu \mathrm{m}$ total thickness $)$. Staining for $\beta$ III-tubulin was quantified using Velocity (Improvision, Coventry, UK) on three-dimensional reconstructions of datasets using an intensity classifier and size exclusion criteria to identify neurites. Images were collected from at least three different randomly selected areas from each of two duplicate cell cultures. Average volume data and total volume per nuclei from each time point and each treatment was compared using a one-way ANOVA, with a Tukey's multiple comparison test (Prism software; GraphPad Software, San Diego, CA).

NMDA puffing. Agonist application experiments on primary cortical cultures between 6 and $14 d$ in vitro (DIV) were performed using a Picospritzer III (Intracel, Frederick, MD) connected to a patch electrode filled with artificial CSF (aCSF) containing $100 \mu \mathrm{m}$ NMDA. The tip of the electrode was placed near a patchclamped cortical neuron, and the maximal response to the agonist was optimized by adjusting the pipette position. Puffs were applied for $30 \mathrm{~ms}$ every $8 \mathrm{~s}$ (20 psi) in the presence of $\operatorname{DNQX}(10 \mu \mathrm{M})$, D-serine $(10 \mu \mathrm{M})$, and bicuculline $(10 \mu \mathrm{M})$. No extracellular $\mathrm{Mg}^{2+}$ was added to these solutions. To create an current-voltage $(I-V)$ relationship for NMDA-evoked currents, we applied NMDA while holding at different potentials ranging from -70 to $+40 \mathrm{mV}$.

Calcium imaging. For $\left[\mathrm{Ca}^{2+}\right]_{\mathrm{i}}$ determinations, subconfluent cortical neurons were cultured on glass coverslips and loaded for $30 \mathrm{~min}$ at room temperature with $5 \mu \mathrm{M}$ fura 2-AM (Invitrogen) aCSF. After loading, cells were kept in aCSF for up to $1 \mathrm{~h}$. Fluorescence was measured as described previously (Grynkiewiecz et al., 1985) using computer-controlled Polychrome II Monochromator (T.I.L.L. Photonics, Martinsried, Germany) with excitation at 340,360 , and $380 \mathrm{~nm}$ and emission detected at $>505$ $\mathrm{nm}$. The ratio of fluorescence at 340 and $380 \mathrm{~nm}$ excitation was used as a measure of $\left[\mathrm{Ca}^{2+}\right]_{\mathrm{i}}$. Fluorescence was detected using a CCD pentamax camera (Princeton Instruments, Trenton, NJ). Data were recorded and analyzed using Meta Imaging (series 7.0) software (Molecular Devices, Sunnyvale, CA). A pair of images was obtained every second with $20 \mathrm{~ms}$ exposure time at each wavelength. Fluorescence measurements were preformed in the cell soma. Only cells with low resting ratios $(<0.5)$ and cells that returned to basal ratios after stimulation were used for analysis.

Electrophysiology. Whole-cell patch-clamp recordings were made from primary cultures of cortical neurons [visualized at $60 \times$ with a Nikon (Tokyo, Japan) E600FN fitted with differential interference contrast optics] using a multiclamp 700B amplifier (Molecular Devices) and pClamp9 software (Molecular Devices). Data were sampled at $50 \mathrm{kHz}$ and filtered at $10 \mathrm{kHz}$. Patch pipettes were pulled from borosilicate glass capillaries (GC150F-7.5; Harvard Apparatus, Edenbridge, UK) using a two-stage vertical puller (PC-10; Narishige, Tokyo, Japan). Tips were polished (Micro Forge; Narishige), and pipettes had a final open-tip resistance of $\sim 5 \mathrm{M} \Omega$ when filled with a patch solution containing the following (in $\mathrm{mm}$ ): $130 \mathrm{CsCl}, 10 \mathrm{HEPES}, 5 \mathrm{EGTA}$, and $1 \mathrm{MgCl}_{2}, \mathrm{pH}$ adjusted to 7.2 with $\mathrm{CsOH}$. Whole-cell access resistances were $<20 \mathrm{M} \Omega$. Bath solution was as follows (in $\mathrm{mm}$ ): $135 \mathrm{NaCl}, 3 \mathrm{KCl}, 10$ HEPES, 2 $\mathrm{CaCl}_{2}, 10$ glucose, and 45 sucrose.

\section{Results}

To explore the role of heme signaling in neuronal survival, we developed a model of heme deficiency using cortical neuron cultures. Treatment with SA, a specific inhibitor of 5-aminolaevulinic acid dehydratase (Tschudy et al., 1981), caused a $>50 \%$ reduction in heme synthesis (Chernova et al., 2006). Continuous treatment for $>2$ weeks created a chronic deficiency in the cortical culture that showed many changes consistent with neurite degeneration.

\section{Inhibition of heme synthesis causes neurodegeneration}

To examine morphological changes, heme-deficient cortical neuron cultures were monitored by staining for the cytoskeletal protein $\beta$ III-tubulin. Immunostaining on 8,10 , and 15 DIV revealed that heme-deficient cultures exhibit neurodegeneration (Fig. 1). In SA-treated cells (Fig. $1 B, E, H$ ), the $\beta$ III-tubulin staining was discontinuous, showing increasing neurite fragmentation and 
disruption in the axonal/dendritic microtubule structure. Fragmentation increased progressively throughout the treatment. By 15 DIV, only a limited number of neurites in the heme-deficient culture were intact (Fig. $1 \mathrm{H}$ ). Neurites in the control cultures remained intact through 10 DIV and by 15 DIV had a few bright spots along some processes, consistent with slight degeneration as a result of aging (Fig. $1 A, D, G)$. Strikingly, cultures treated with SA and heme maintained a well established network of projections for the entire duration of the experiments, showing only minor fragmentation of neuronal processes with age in culture and far less than in the SA-treated samples (Fig. 1C,F,I).

To quantify neurite fragmentation, staining for $\beta$ III tubulin was assessed on three-dimensional reconstructions of datasets. Total volume per nuclei was used as a measure of equality between cell numbers in image fields examined (Fig. $1 \mathrm{~J}$ ). No significant differences were found between control and treatments, indicating that the sampling was free from cell density bias. Average neurite volume per cell was used as a measure of neurite fragmentation and was compared between all treatments at each time point (Fig. $1 \mathrm{~K}$ ). Significant differences were found between control and heme-deficient neurons at 10 and 15 DIV. Heme replacement essentially prevented fragmentation of neurites at all ages. To determine whether this observation reflects cell death-independent degeneration, we applied a viability/cytotoxicity assay. The proportion of live and dead cells was assessed using fluorescent microscopy at 5, 9, and 14 DIV. No significant difference was observed at these time points between controls and any of the treatments.

The results of a cell viability assay conducted on 16, 19, and 22 DIV showed that long-term treatment with SA eventually results in death of the cell body after 3-4 weeks (supplemental Fig. 1, available at www.jneurosci.org as supplemental material). The proportion of dead cells after $16 \mathrm{~d}$ of treatment was $34 \pm 4 \%$ (compared with $29 \pm 5 \%$ in control culture), but the loss of the projections at this stage was dramatic as reflected in Figure $1 \mathrm{H}$. By $19 \mathrm{DIV}$, the number of dead cells increased to $60 \pm 5 \%$, whereas virtually all neurites were fragmented. On $22 \mathrm{DIV}$, the culture had no visible neurite network, and $95 \pm 4 \%$ of the cells were dead. Control cultures on 22 DIV still had a well established neurite network, and the number of dead cells was $48 \pm 4 \%$.

\section{Heme depletion and restoration are reflected in Alas1 and Hmoxl expression}

Our model was based on sustained 70\% reduction of heme synthesis by treatment with $0.5 \mathrm{~mm}$ SA. Inhibition of heme synthesis by SA caused upregulation of Alas1, the first and rate controlling enzyme (Fig. 2B) as a result of end-product negative feedback regulation (Sassa and Nagai, 1996). Heme as hemin was used in reconstitution experiments at physiologically relevant levels, i.e.,
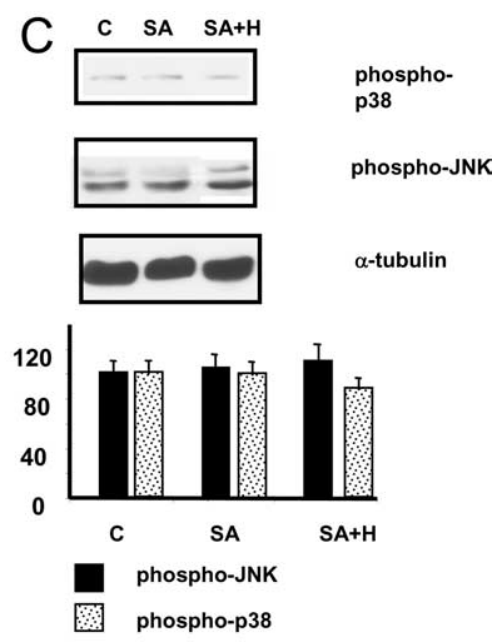

D

C SA SA+H

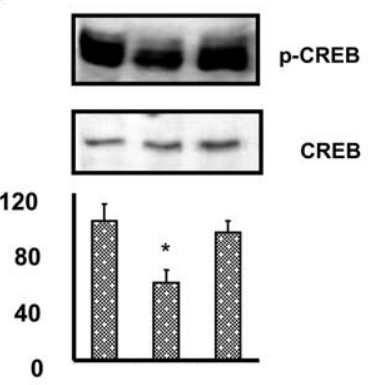

Figure 3. Rescue effect of heme on basal activation of ERK1/2 pathway in the neurons with inhibited heme synthesis and aged mice and cultured for 14 or $21 \mathrm{~d}$, respectively. Treatment with $0.1 \mu \mathrm{m}$ hemin $(\mathrm{H})$ was conducted for the entire length 0 phospho- CREB and total CREB $(\boldsymbol{D})$. Each column is the mean \pm SD normalized expression of protein of three independent experiments. ${ }^{*} p<0.05 ;{ }^{* *} p<0.01$. C, Control.

0.1-1 $\mu \mathrm{M}$ for microsomal- and cytosol-free heme, respectively (Granick et al., 1975). At $0.1 \mu \mathrm{M}$ used in our model, hemin inhibited induction of Alas1 in SA-treated cells (Fig. 2B) but did not induce Hmoxl (Fig. 2C). Raising intracellular free heme above $0.1 \mu \mathrm{M}$ would be expected to cause rapid metabolism attributable to the inducible isoform of HMOX and trigger a cascade of secondary effects of Hmoxl induction. A threefold Hmoxl induction, observed in SA-treated cells (Fig. 2C), was associated with increased sensitivity of heme-deficient neurons to oxidative stress (supplemental Fig. 2, available at www.jneurosci.org as supplemental material). Treatment with $0.1 \mu \mathrm{M}$ hemin enabled us to restore internal heme level and avoid effects of Hmoxl induction (Fig. $2 B, C$ ).

Heme deficiency impairs basal activation of ERK1/2 pathway Previously, we have shown that heme deficiency suppresses NMDAR subunit expression and causes premature neuronal aging (Chernova et al., 2006). The prosurvival ERK1/2 pathway is a plausible candidate implicated in these processes. To determine the mechanisms of impaired neuronal survival, we examined the status of the ERK1/2 pathway in pharmacologically (SA) and genetically (Fech ${ }^{\text {m1Pas }}$ mouse) induced heme deficiency. The 
A
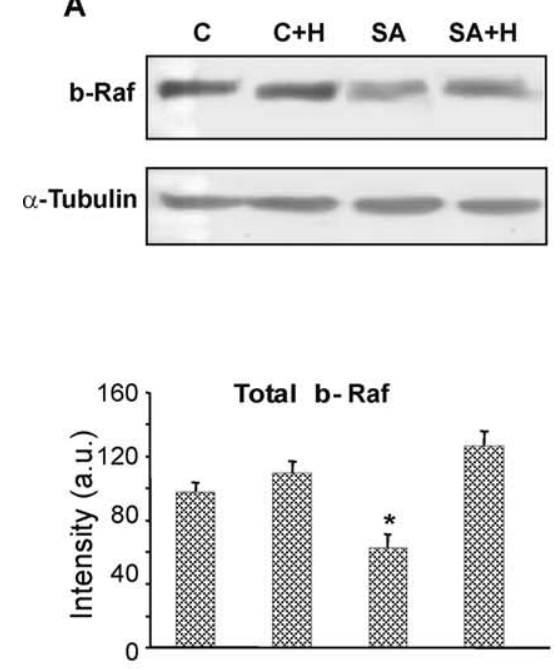

$\mathrm{Bi}$
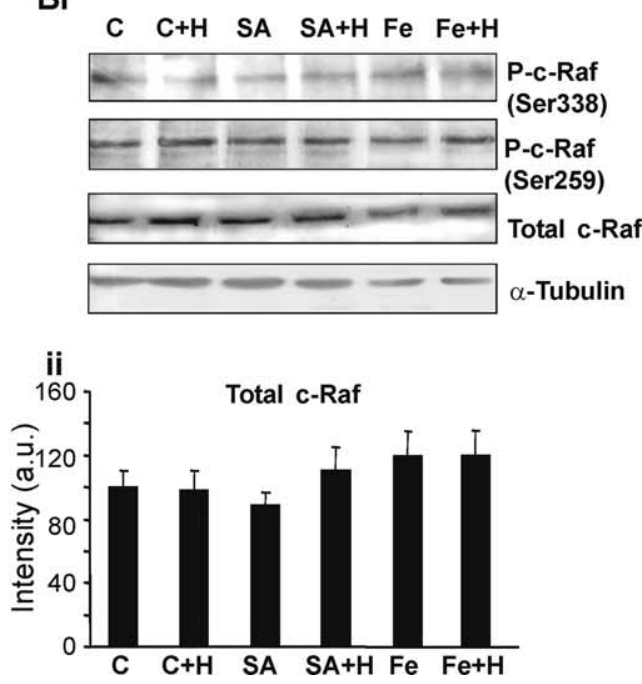
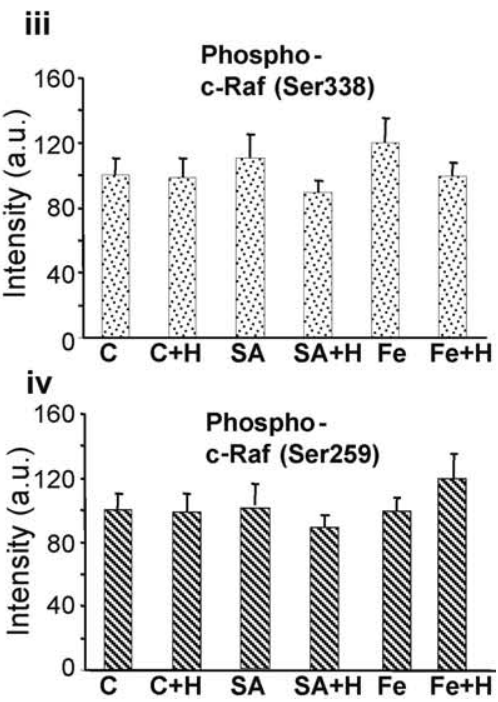

Figure 4. Expression and phosphorylation of b- and c-Rafin heme-deficient and heme-sufficient cortical neurons. Western blots were performed on cultured BALB/c neurons treated with SA and hemin for $14 \mathrm{~d}$. Neurons from Fech ${ }^{m 1 \text { Pas }}$ mouse were treated with hemin for $24 \mathrm{~h}$ before harvesting. $A$, Decreased expression of b-Raf in SA-treated neurons. Twenty micrograms of proteins in total cell lysates were analyzed by Western blot, probing for total b-Raf, and the same blots were reprobed for $\alpha$-tubulin. Each column is the mean \pm SD of total b-Raf/ $\alpha$-tubulin ratio of three independent experiments. C, Control; H, heme. Bi, Immunoblotting showing that treatment with SA and/or heme did not have any effect on expression of c-Raf and its phosphorylation at Ser338 or at Ser259. The same blots were reprobed for $\alpha$-tubulin. Bii-iv, Quantification of these data, with each cxolumn being percentage ratio \pm SD of three independent experiments for total c-Raf: $\alpha$-tubulin (ii); phospho-c-Raf (Ser338):total c-Raf (iii); and phospho-c-Raf (Ser259):total c-Raf (iv).

Fech ${ }^{\text {m1Pas }}$ mouse carries a point mutation in the gene encoding the enzyme ferrochelatase (Boulechfar et al., 1993) with subsequently lowered ferrochelatase activity and heme synthesis decreased by $40 \%$ (Chernova et al., 2006). Activation of ERK1/2 was diminished in heme-deficient cultures treated with SA and in neurons derived from Fech ${ }^{\text {m1Pas }}$ mice (Fig. 3A). Treatment with exogenous heme restored activation of ERK1/2 in both cases. Similar effects were measured in aged cultures at 21 DIV (Fig. $3 B$ ). The response to exogenous heme was eliminated by a $30 \mathrm{~min}$ incubation of SA and heme-treated cells with the MAPK kinase (MEK1/2) inhibitor U0126, but inhibition of phosphatidylinositol 3-kinase (PI3K), PKA, and PKC (by treatment with LY294002, GF109203X, or Ro 31-8220, respectively) did not attenuate the rescue effect of heme on ERK1/2 phosphorylation (Fig. 3A). Involvement of other mitogen-activated kinases associated with cell growth and differentiation is unlikely, because Western blot analysis with anti-phospho-stress-activated protein kinase/JNK and anti-phospho-p38 MAPK showed no difference in control and SA-treated cells with and without heme replacement (Fig. $3 C$ ). Immunoblotting suggested that CREB is the downstream effector of ERK1/2 activation by exogenous heme in heme-deficient neurons (Fig. 3D).

\section{Rescue of ERK1/2 activation by heme requires b-Raf but not c-Raf}

These above results indicate that the survival signaling of heme is specifically mediated by the ERK1/2 pathway, upstream of MEK1/2 and independent of PI3K, PKC, or PKA. To test for upstream affectors of ERK1/2, we measured c-Raf and b-Raf kinases in the heme-depletion model. In the highly conserved Ras/ Raf/MEK/ERK signaling pathway, different Raf isoforms activate MEK in a range of cell types (Mercer et al., 2002; Zhu et al., 2002). Expression of b-Raf is highly correlated with its activity (Dwivedi et al., 2006) and was significantly lower in heme-deficient neurons compared with control cultures but was rescued by heme addition (Fig. 4A). Exogenous heme did not alter the expression of b-Raf in untreated neurons. Conversely, the total amount of
c-Raf and its phosphorylation at both Ser338 and Ser259 was not affected by impaired heme synthesis in both SA-treated and $\mathrm{Fech}^{\mathrm{mlPas}}$ neurons and did not change during heme reconstitution. Treatment of control cells with additional heme also did not alter either expression or activation of c-Raf (Fig. 4B). c-Raf Ser259 is an inhibitory site (Moelling et al., 2002) and effective on ERK1/2 in neuronal cells (Subramaniam et al., 2005). Inhibited heme synthesis in PC12 cells treated with NGF caused diminished phosphorylation of c-Raf at Ser259 (Zhu et al., 2002). Our results therefore suggest an important difference between signaling transduction in cell lines and primary neuronal cells in that b-Raf, but not c-Raf, is involved in ERK1/2 modulation.

\section{Exogenous heme has a differential effect on phosphorylation} of NMDAR subunits

The observed loss of neurite integrity and consequent loss of connectivity in heme-deficient cultures could severely impair synaptic signaling and impact on expression of synaptic receptors. Activation of the ERK1/2 signaling pathway is dependent on calcium influx through synaptic NMDARs (Sweatt, 2004); therefore, prosurvival stimulation of ERK1/2 by heme replacement in SA-treated neurons should correlate with NMDAR expression. It is known that heteromeric assembly of NR1 and NR2 is necessary for functional NMDAR channels (Dingledine et al., 1999). Using real-time PCR, we established that the most highly expressed NMDAR subunits at 14 DIV were NR1 and NR2B (data not shown). Expression of NR1 and NR2B was reduced in SA-treated and aged neurons. Heme replacement restored protein expression under both conditions (Fig. 5A,B). Pharmacological inhibition of MEK1/2 activity during heme replacement had no effect on NR1 expression (Fig. 5A).

NMDAR phosphorylation also regulates channel kinetics and membrane localization/trafficking (Cull-Candy et al., 2001) so we measured phosphorylation of NR1 at three serine sites namely: serine 890 and 896, which are PKC regulated, and serine 897, which is phosphorylated by PKA (Tingley et al., 1993, 1997). As shown on Figure $5 C-E$, phosphorylation of all the three sites was 
reduced in heme-deficient neurons, whereas heme replenishment rescued only PKC-dependent phosphorylation at Ser890. Additional incubation with two different PKC inhibitors, Ro 31-8220 (10 $\mu \mathrm{M})$ or GF109203X (1 $\mu \mathrm{M})$ for $30 \mathrm{~min}$ before harvesting eliminated this heme effect. Application of the PI3K inhibitor 50 $\mu \mathrm{M}$ LY294002 or MEK1/2 inhibitor U0126 did not alter the rescue effect of heme on Ser890 phosphorylation, whereas inhibition of the ERK1/2 pathway at MEK1/2 level augmented Ser890 phosphorylation by PKC in SA- and heme-treated cells. This finding suggests a compensatory enhancement of NMDAR channel activity and $\mathrm{Ca}^{2+}$ influx when the prosurvival pathway is blocked. Phosphorylation of Ser896 is also PKC dependent, but it remained low after heme replacement. The other data show that PKA-dependent phosphorylation of NR1 did not recover during heme replacement, and inhibition of the ERK1/2 pathway caused no compensatory increase in phosphorylation at Ser896 and Ser897.

$\mathrm{NR} 2 \mathrm{~B}$ is the main tyrosinephosphorylated protein regulated by Src family kinases (SFKs) in the postsynaptic density (Moon et al., 1994). Phosphorylation at Tyr1336 was virtually absent in heme-deficient neurons and entirely restored in the presence of heme (Fig. $5 F$ ). In parallel with the increased NR1 Ser890 phosphorylation with MEK1/2 inhibition, Tyr1336 phosphorylation was markedly higher in SA- and heme-treated cells (Fig. $5 F$ ). These data suggest that NMDAR activity is upstream of ERK $1 / 2$ and is either a possible effector for ERK1/2 or part of another parallel regulatory pathway in which heme also plays a protective role.

\section{Neuronal rescue by heme replacement is abolished by NMDAR block}

NMDAR activity is regulated by numerous endogenous modulators, including activation by serine-threonine and tyrosine phosphorylation. To elucidate the mechanism by which heme is involved in the activation of the prosurvival ERK1/2 pathway, we blocked NMDAR activity in SA- and heme-treated cells, using the competitive inhibitor AP-5 $(50 \mu \mathrm{M})$ and abolished the stimulatory effect of heme on ERK1/2 in heme-depleted culture (Fig. 6A). Another way of suppressing NMDAR gating is by inhibiting the members of the SFKs, which enhance NMDAR function. Inhibition of SFKs by PP2 eliminated the activation of ERK1/2 by added heme (Fig. 6B). Inhibition of NR2Bcontaining NMDARs using the selective antagonist ifenprodil $(10 \mu \mathrm{M})$ (Williams, 1993) blocked the rescue effect of heme on ERK1/2. Together, these data provide strong evidence that the rescuing effect of heme is NMDAR dependent and mediated via NR2B-containing NMDARs.

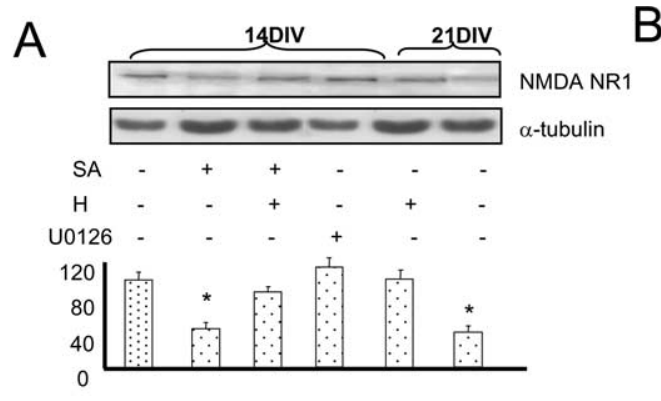

B
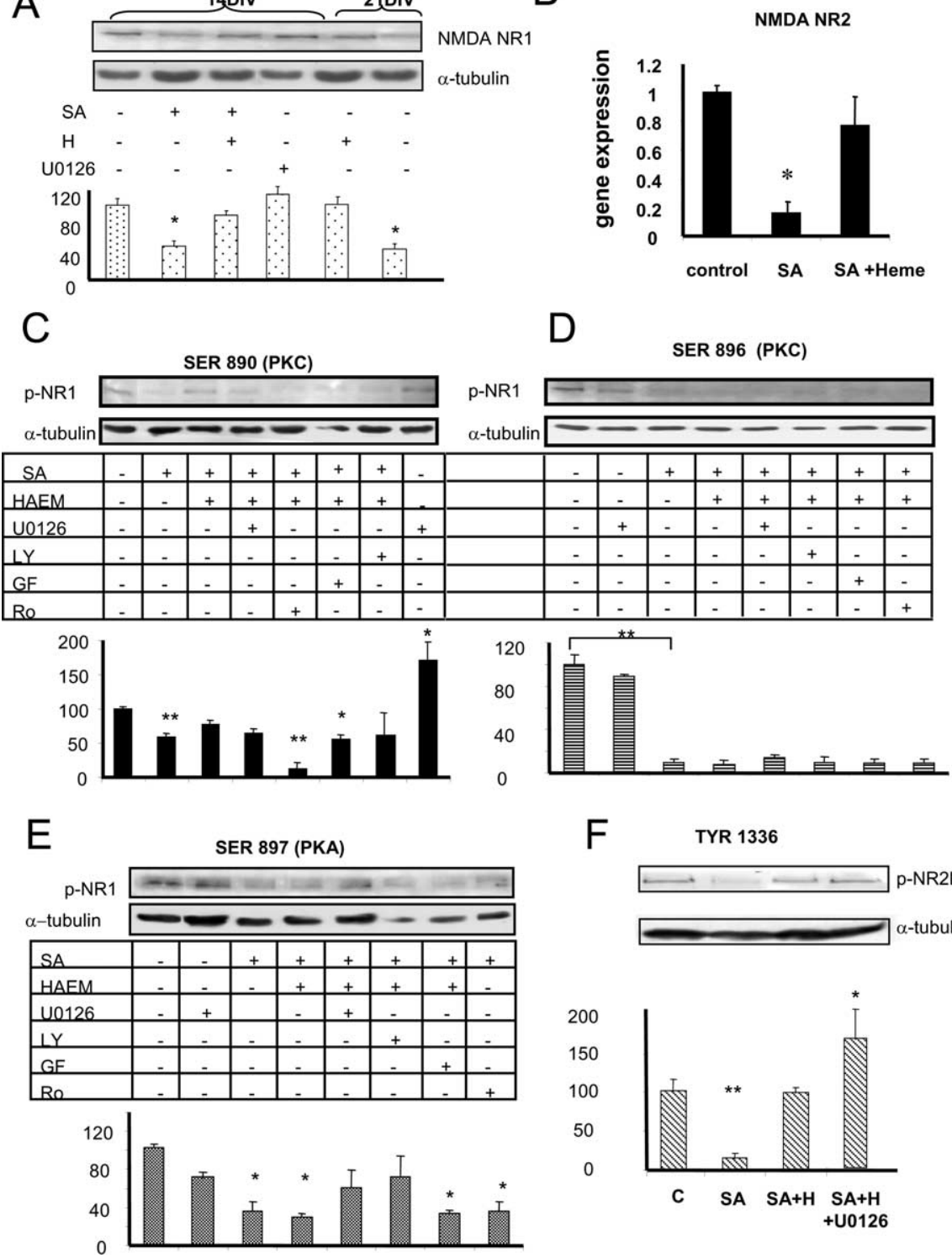

F

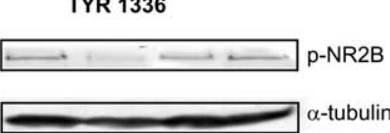

Figure 5. Differential effect of heme on total expression and phosphorylation of NMDAR subunits in heme-deficient neurons. with $1 \mu \mathrm{M}$ GF109203X (PKA inhibitor at $2 \mu \mathrm{m}$ and PKC inhibitor at $10 \mathrm{~nm}$ ), and with $10 \mu \mathrm{M}$ Ro 31-8220 (PKC inhibitor at nanomolar micrograms of proteins were loaded for each sample, probing for total NR1 (A), phospho-NR1 (Ser890) (C), phospho-NR1 (Ser896) (D), phospho-NR1 (Ser897) $(\boldsymbol{E})$, phospho-NR2B (Tyr1336) $(\boldsymbol{F})$, and $\alpha$-tubulin. Each column is the mean \pm SD of NMDAR/ $\alpha$ tubulin ratio of three independent experiments. C, Control. ${ }^{*} p<0.05$; ${ }^{* *} p<0.01$.

\section{Heme depletion reduces NMDA-evoked and voltage-gated sodium currents}

Although we can clearly demonstrate molecular changes in NMDARs on heme depletion, it was important to establish whether these changes were directly translated into differences in NMDAR expression in the neuronal membrane and/or to determine whether other ionic channels may be involved. Whole-cell patch-clamp recordings were made from single cortical neurons maintained in tissue culture under identical conditions to the above experiments. The voltage-gated and leak potassium currents were similar in control and heme-depleted cultures, as shown in the $I-V$ relationship in Figure $7 A$. However, there was a strong reduction of voltage-gated $\mathrm{Na}^{+}$currents in response to SA 
A
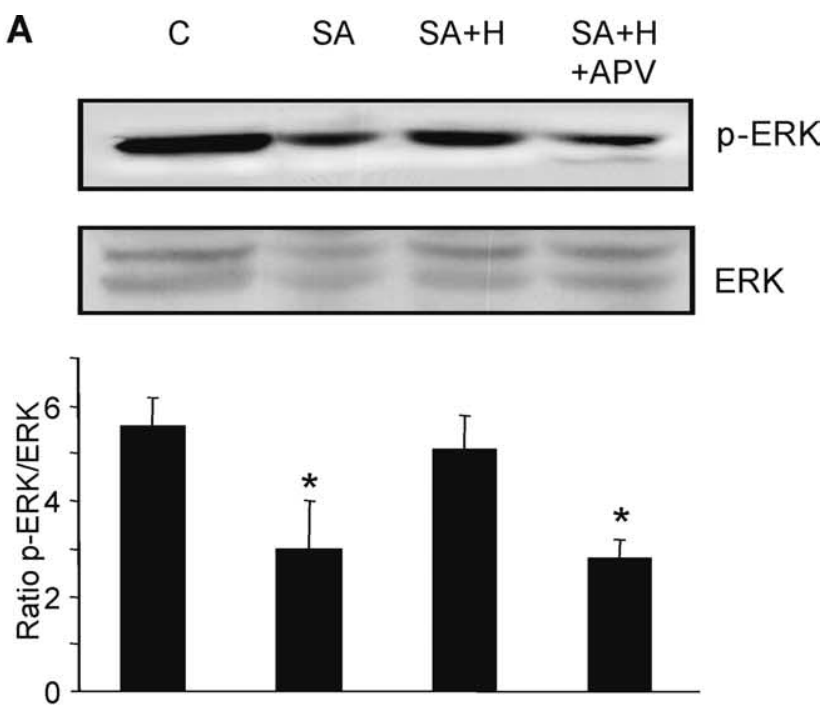

B
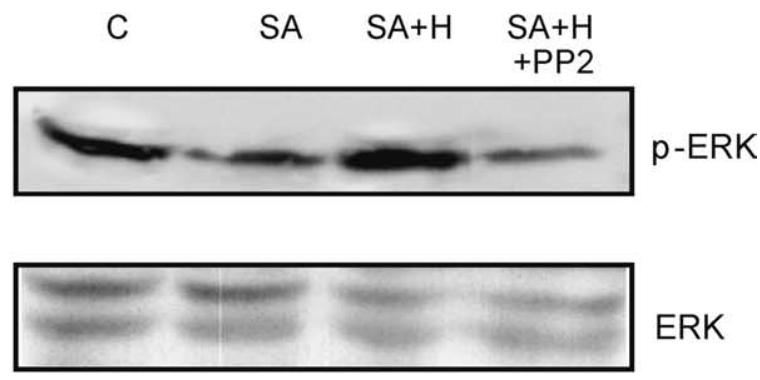

ERK

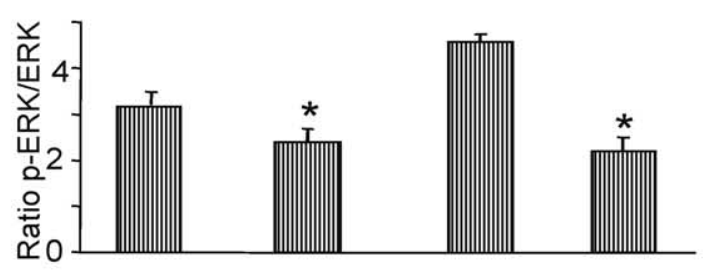

C

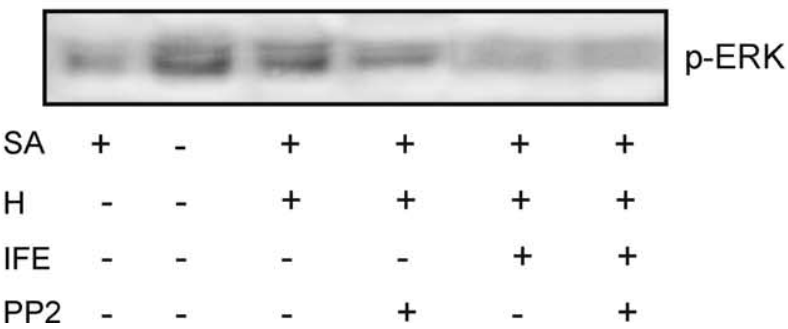

Figure 6. Effects of NMDAR inhibition on the rescue of ERK1/2 phosphorylation by heme. $\boldsymbol{A}$ Cortical neurons treated for $14 \mathrm{~d}$ with SA and heme were incubated for 30 min with the competitive NMDAR antagonist $50 \mu \mathrm{m}$ APV. Total cell lysates were analyzed by immunoblotting to detect activated ERK1/2. The bottom shows the same blot reprobed with an antibody recognizing total ERK1/2. $\boldsymbol{B}$, Cortical neurons treated for $14 \mathrm{~d}$ with SA and heme $(\mathrm{H})$ were incubated for 30 min with SFK inhibitor PP2 (1 $\mu \mathrm{M})$. Equal amounts of protein extracts were analyzed by Western blot with phospho-ERK1/2 antibody. The bottom shows the same blot reprobed with anti-total ERK1/2 antibody. C, Cortical neurons treated for $14 \mathrm{~d}$ with SA and heme were incubated for 30 min before harvesting with $10 \mu \mathrm{M}$ ifenprodil (IFE) and with $1 \mu \mathrm{M}$ PP2. Each column is the mean \pm SD of phospho-ERK1/2/ERK1/2 ratio from three independent experiments. ${ }^{*} p<0.05$. C, Control.

treatment, which recovered with heme replacement (Fig. $7 B$ ). NMDA currents were measured in the absence of extracellular magnesium ions so as to avoid voltage-dependent block at negative holding potentials. Pressure application of NMDA (100 $\mu \mathrm{M}$,
$30 \mathrm{~ms}$ ) was used over a range of holding potential to generate an $I-V$ relationship in control cultures and compared with $I-V \mathrm{~s}$ recorded from SA-treated neurons at similar ages ( $>12$ DIV). Heme depletion resulted in significantly reduced NMDAmediated whole-cell current (Fig. $7 C$, raw traces). The halfduration for these NMDA currents $\left(t_{(1 / 2)}\right.$, measured at $-70 \mathrm{mV}$ in the absence of $\left[\mathrm{Mg}^{2+}\right]_{\mathrm{o}}$ ) increased after SA treatment and did not completely recover with heme replacement (Fig. 7C, insets) $\left(t_{(1 / 2) \text { control }}=1.45 \pm 0.28 \mathrm{~s}, n=8, t_{(1 / 2) \mathrm{SA}}=3.1 \pm 1.32 \mathrm{~s}, n=6\right.$; $\left.t_{(1 / 2) \mathrm{SA}+\text { heme }}=2.64 \pm 0.19 \mathrm{~s}{ }^{* *}, n=6 ;{ }^{* *} p<0.01\right)$. A summary of data averaged across the age range of $6-13$ DIV is shown in Figure $7 D$, with data from SA-treated cells normalized to current magnitudes in control cells at 12 DIV. Leak currents were measured at $-110 \mathrm{mV}$, voltage-dependent outward $\mathrm{K}^{+}$currents (highvoltage-activated $I_{\mathrm{K}}$ ) were measured at $+30 \mathrm{mV}$, voltage-gated $\mathrm{Na}^{+}$currents $\left(\mathrm{Na}_{\mathrm{v}}\right)$ were measured at $-20 \mathrm{mV}$, and NMDAevoked whole-cell currents $\left(I_{\mathrm{NMDA}}\right)$ were measured at $+40 \mathrm{mV}$. Both $\mathrm{Na}_{\mathrm{v}}$ and $I_{\mathrm{NMDA}}$ were significantly reduced after $12 \mathrm{~d}$ of heme depletion. NMDA and $\mathrm{Na}^{+}$currents exhibited age-dependent changes in magnitude, showing a developmental increase under control conditions over 6-11 DIV. NMDA currents were significantly reduced in SA-treated cells at all ages, but surprisingly, heme replacement did not restore NMDA current amplitudes to control levels at 13 DIV (Fig. 7C,E).

Voltage-gated $\mathrm{Na}^{+}$currents showed an initial augmentation in SA-treated cultures, consistent with accelerated senescence and then strongly declined to $<20 \%$ control levels by 13 DIV (Fig. 7F). Heme replacement dramatically enhanced $\mathrm{Na}_{\mathrm{v}}$ currents.

\section{Heme replacement favors NMDAR channels that exhibit higher calcium permeability}

The above electrophysiological data on NMDA currents appears in conflict with previous data showing that heme replacement restores NMDAR expression to control levels. Because NMDARs are highly $\mathrm{Ca}^{2+}$ permeable (Schneggenburger et al., 1993), we also investigated the intracellular $\mathrm{Ca}^{2+}$ changes in response to NMDA application using fluorescent indicators. Cortical neuron cultures were loaded with fura-2 AM, and NMDA was pressure applied onto control neurons and SA-treated and SA plus hemetreated cells at $12 \mathrm{DIV}$. SA treatment greatly reduced intracellular $\mathrm{Ca}^{2+}$ responses to NMDA (Fig. 8A,D). Neurons that were cotreated with $\mathrm{SA}$ and heme exhibited $\mathrm{Ca}^{2+}$ influxes similar to those of control cells (Fig. 8A). This differs from the electrophysiological data in which NMDAR currents remained depressed after heme replacement but may be reconciled if the NMDAR expressed on heme restoration were to possess higher calcium permeability. To test this possibility, we compared reversal potentials $\left(E_{\mathrm{r}}\right)$ of the NMDA-evoked currents in the three groups (control, SA treated, and heme replaced), and, to avoid agedependent issues, all data were collected from 12 DIV cultures. A change in $E_{\mathrm{r}}$ of the whole-cell current would reflect a change in ion permeabilities of the NMDA receptor because $\mathrm{Na}^{+}$and $\mathrm{Ca}^{2+}$ have very positive reversal potentials $(>50 \mathrm{mV})$. The $E_{\mathrm{r}}$ of the whole-cell current in SA-treated and control cells as shown in the $I-V$ relationship in Figure $8, B$ and $C$, indicates a slight shift toward more negative values in the SA group (summarizing all ages between 6 and 13 DIV). Because the difference in NMDA currents between control and SA becomes more prominent in older neurons (12 DIV), we decided to exclusively analyze reversal potentials at this time in culture. Mean $E_{\mathrm{r}}$ values of NMDAevoked whole-cell currents were significantly shifted from $5.0 \pm$ 
1.5 to $0.8 \pm 0.8 \mathrm{mV}$ by SA treatment and reversed back to $6.6 \pm 1.2 \mathrm{mV}$ by heme readmission (Fig. $8 E$ ).

\section{Discussion}

Using heme depletion of cortical neurons in primary culture, we have shown that heme deficiency leads to a morphological phenotype similar to that seen in slow neurodegenerative diseases. We demonstrate that inhibition of heme synthesis causes neurodegeneration via NMDARdependent suppression of the ERK $1 / 2$ pathway. Reduced NMDAR expression is combined with changes in the relative $\mathrm{Ca}^{2+}$ permeability of functional NMDARs and reduced calcium influx. Associated reductions in voltage-gated sodium currents with heme depletion would further compromise neuronal signaling. These results provide important new insights into how compromised heme synthesis and availability influence key aspects of neuronal signaling associated with neurodegeneration and aging.

In a previous study, we characterized this heme-depletion model as exhibiting key features of senescence (Chernova et al., 2006), and here we demonstrate that heme deficiency causes neurite degeneration. This model is based on specific inhibition of 5-aminolaevulinic acid dehydratase by succinyl acetone. Consistent with suppression of heme synthesis, we demonstrated increased expression of the heme ratelimiting enzyme ALAS1 (Sassa and Nagai, 1996). Use of low heme concentrations $(0.1 \mu \mathrm{M})$ during the heme replacement in SA-treated cultures avoided upregulation of Hmox1, which could otherwise aggravate heme depletion by increasing heme catabolism. Lowered Hmoxl expression during heme replacement suggests that induction is triggered by heme deficiency and that the protective effect of heme is related to heme per se and not to HMOX1 induction.

The progressive fragmentation of neurons without an increase in cell soma loss caused by heme depletion resembles the early progress of many neurodegenerative diseases and age-related dementias. Our purpose here was to explore the molecular signaling pathways leading from compromised heme metabolism to neurodegeneration. A recent study has demonstrated that activation of ERK1/2 in primary neurons delays Wallerian degeneration of synaptic terminals induced by proteasome inhibitors (MacInnis and Campenot, 2005).

Neuronal processes may be more sensitive to heme-related mitochondrial dysfunction attributable to their decreased size compared with the cell soma and therefore the inability to buffer or compensate for even small functional changes. The rescue of neurons from neurodegenerative changes by exogenous heme indicates the specificity of the phenomenon and is consistent with
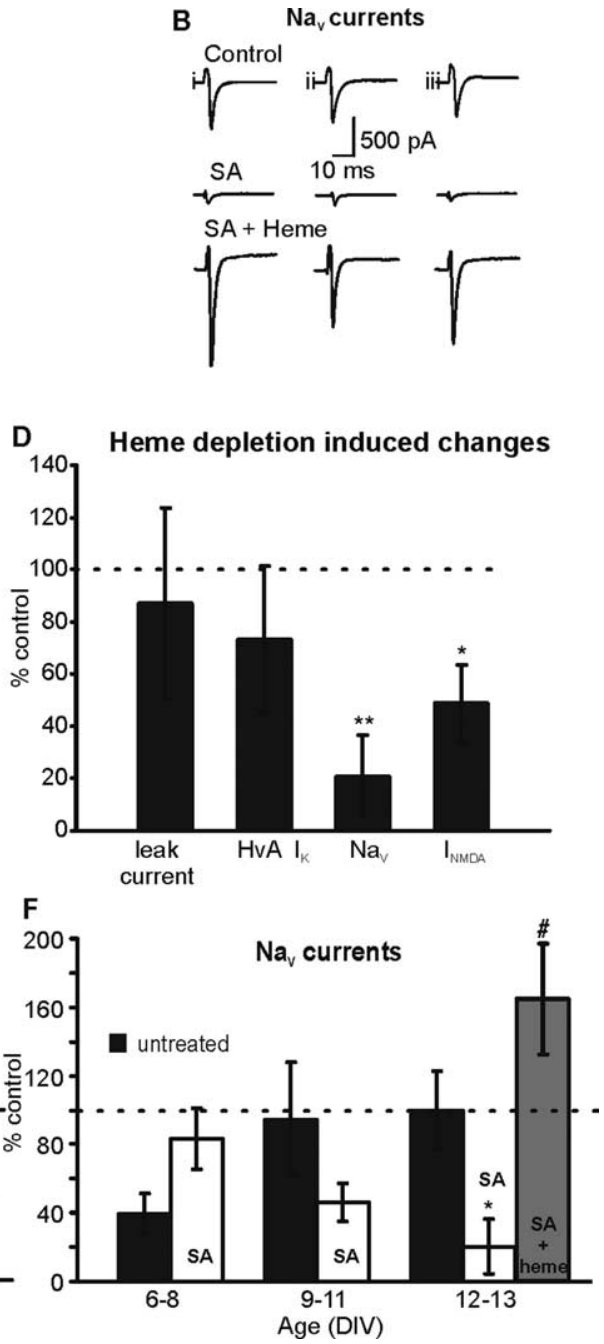

Figure 7. Heme depletion reduces NMDA and voltage-gated sodium currents but not potassium currents. $\boldsymbol{A}, I-V$ relationship of primary cultured cortical neurons at 12-13 DIV (control vs SA treatment) shows no change in leak or voltage-activated outward holding potential from -70 to $-20 \mathrm{mV}$ for cells treated with SA and SA in the presence of heme. $\boldsymbol{C}$, Whole-cell currents evoked in the change in decay kinetics. D. Summary of ionic current changes caused by heme depletion. Mean data are normalized expressed relative to control values in 12 DIV cells. Both $I_{\mathrm{Na}}$ and $I_{\mathrm{NMDA}}$ were significantly reduced. $\boldsymbol{E}$, NMDA currents increased with days in culture. Mean data for untreated, SA-treated, and SA plus heme-treated cells are normalized to control values at 12 DIV cells. $\boldsymbol{F}$, Voltage-activated $\mathrm{Na}^{+}$currents increased with days in culture. Mean data for untreated, SA-treated, and SA plus initial augmentation at $6-8$ DIV. Heme replacement reestablished these current at 13 DIV. Data denote mean \pm SEM of at least six different cells per data point. Significant differences are shown using Student's unpaired $t$ test; ${ }^{*} p<0.05,{ }^{* *} p<0.01$ compared with control; ${ }^{\#} p<0.05$ relative to SA treatment.

promotion of neuroblastoma neurite outgrowth by exogenous heme but not biliverdin (Ishii and Maniatis, 1978).

Functional heme deficiency could be a contributing factor to Alzheimer's disease (Atamna and Boyle, 2006). Our results characterize mechanisms involved in pathogenesis of heme deficiency-induced neurodegeneration. Although it is possible that neuronal rescue effect of heme is mediated by the metabolic products $\mathrm{CO}$ and biliverdin, treatment with bilirubin did not rescue neurons from neurodegeneration (data not shown), hence it is more plausible that the heme molecule itself has a regulatory role.

We found that the damage induced by heme deficiency and the rescue by heme replacement were mediated via the ERK1/2 

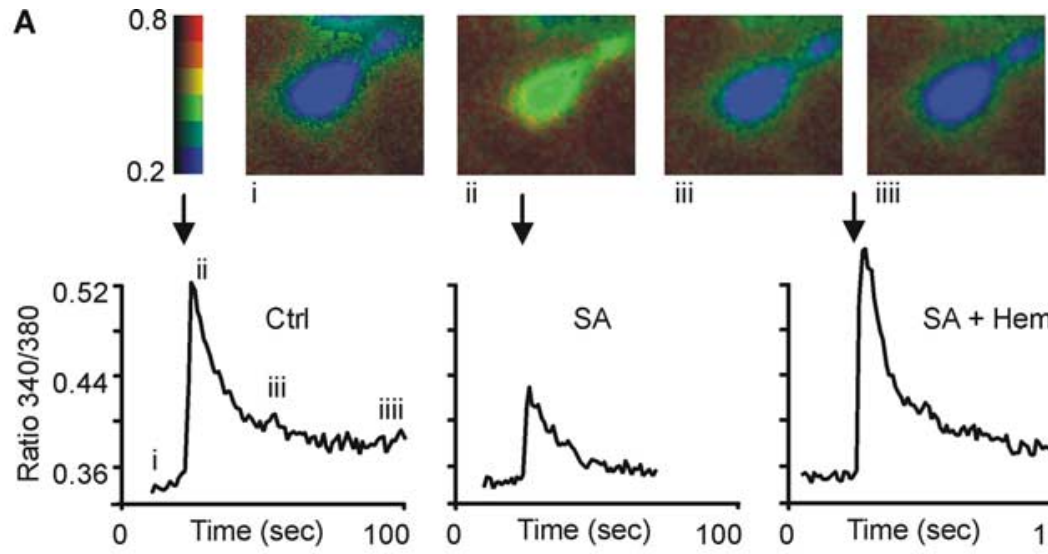

iiii
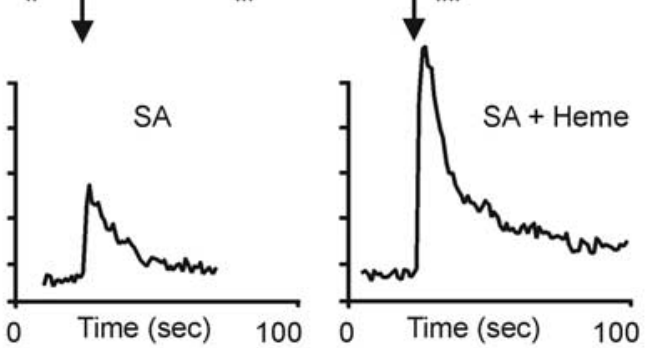

B
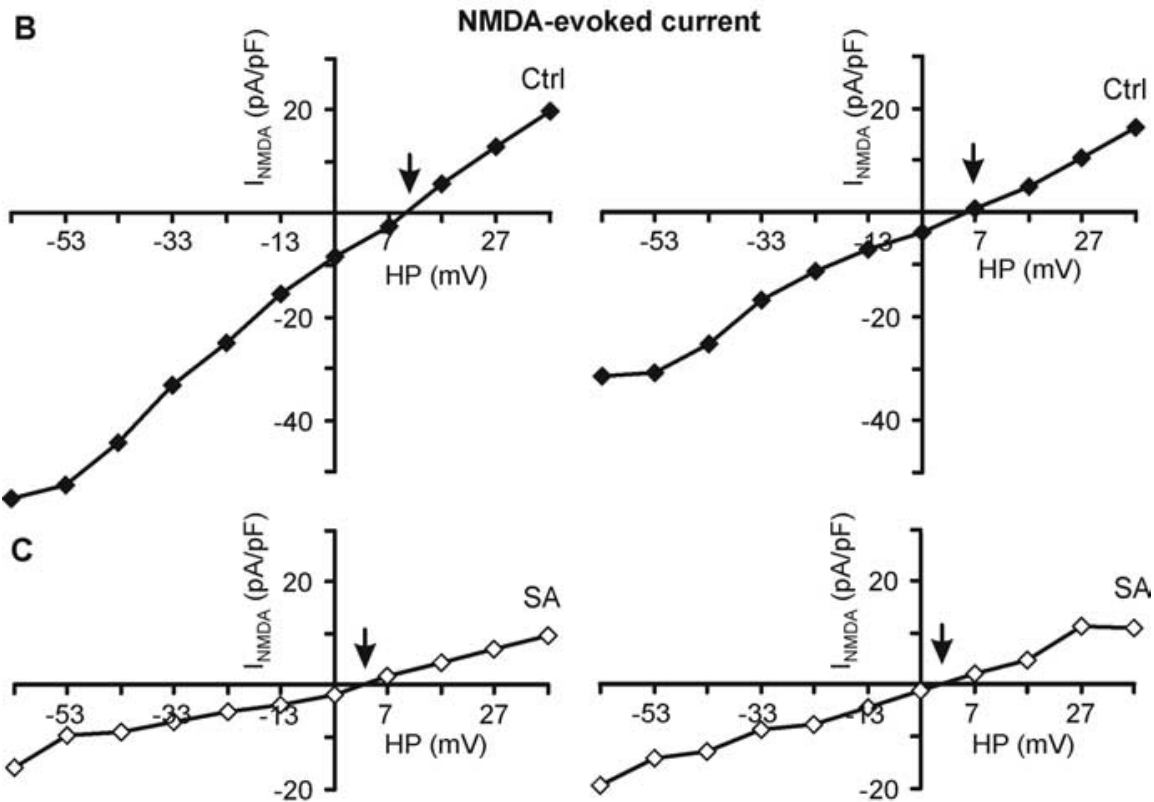

D

$$
\left[\mathrm{Ca}^{2}\right]_{\mathrm{i}}
$$

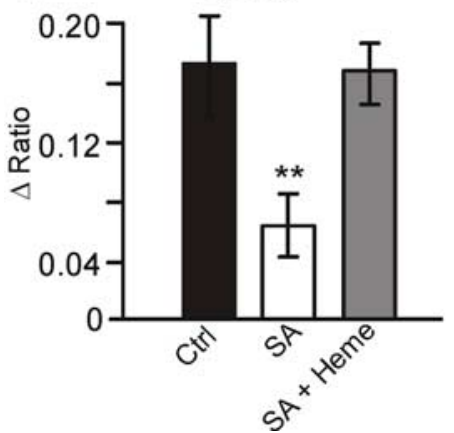

E

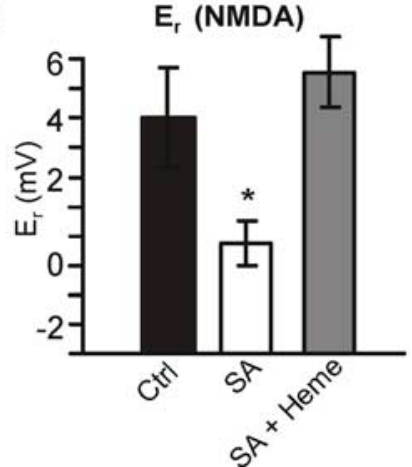

Figure 8. Heme depletion reduces NMDA-evoked $\mathrm{Ca}^{2+}$ influx. $\boldsymbol{A}$, Representative traces of intracellular $\mathrm{Ca}^{2+}\left(\left[\mathrm{Ca}^{2+}\right]_{\mathrm{i}}\right)$ recordings (expressed as 340/380 $\mathrm{nm}$ ratio) in control cells (Ctrl), cells treated with SA, and cells treated with SA plus heme at 12 DIV. Top, False color images taken at indicated time points. $\boldsymbol{B}$, NMDA-evoked $I-V$ relationships of two control cells at 12 DIV. Note that the arrows indicate the $E_{\mathrm{r}} C, I-V$ relationships of NMDA-evoked currents in SA-treated cells at 12 DIV. Note the negative shift in reversal potential compared with controls in $\boldsymbol{B}$. D, NMDA-evoked $\Delta$ ratio (peak-basal intracellular $\mathrm{Ca}^{2+}$ ) is reduced after $S A$ treatment and recovered by heme replacement. $\boldsymbol{E}, E_{\mathrm{r}}$ of control and $S A$-treated cells. $E_{\mathrm{r}}$ is shifted to more negative values after $S A$ treatment and reversed to control after heme replacement. Data denote mean \pm SEM of at least six different cells per data point. ${ }^{*} p<0.05 ;{ }^{* *} p<0.01$. HP, Holding potential.

pathway, which is a key regulatory cascade of neuronal survival. Similar results were observed in the $\mathrm{Fech}^{\mathrm{mlPas}}$ transgenic mouse and in SA-treated neurons, directly linking the phenomenon with heme synthesis. The phosphorylation of ERK2, which is the isoform of greater importance (English and Sweatt, 1996; Saba-El-Leil et al., 2003), was fully reestablished by exogenous heme in SA-treated cells and to lesser degrees in the Fech ${ }^{\text {mlPas }}$ neurons and aged neurons. The modulatory effect of heme on ERK1/2 activation was not compromised by PI3K, PKC, or PKA inhibitors, nor did cell signaling change 38 MAPK or JNK activation, indicating specificity of heme signaling to the ERK1/2 pathway. The activity of Raf kinases is proportional to their expression level (Dwivedi et al., 2006). Decreased b-Raf rather than c-Raf expression was implicated in heme deficiency, whereas recovery on heme replacement confirmed that b-Raf kinase is required for ERK1/2 activation by heme.

Direct or indirect upstream regulators of ERK1/2 include Ras, Src, glutamate (via NMDAR increased gating), $\mathrm{Ca}^{2+}, \mathrm{Zn}^{2+}$, calcium/calmodulin-dependent kinase II, and some growth factors (Subramaniam and Unsicker, 2006). NMDAR-dependent activation of ERK1/2 has been reported in various scenarios of cellular signaling (Sala et al., 2000; Sweatt, 2001; Kim et al., 2005). NMDAR expression is reversibly reduced in heme-deficient cells (Chernova et al., 2006). The alterations in NMDA signaling seen in heme-depleted primary neurons could be a factor in neurite decay. The NMDAR is coupled to the ERK1/2 pathway by a direct interaction between NR2B and RasGRF1, a Ras-specific GDP/GTP exchange factor (Krapivinsky et al., 2003). Our current data show that heme replacement rescued phosphorylation only at the NMDAR1 Ser890 site and that restoration of NMDAR currents is incomplete (see below). Conversely, the decrease in NR2B expression and phosphorylation in SAtreated neurons is well correlated with neurodegeneration and the rescue by exogenous heme, suggesting that NR2Bcontaining NMDA receptors serve as predominant activators of ERK1/2 in these cortical neuronal cultures. It is also possible that the impaired tyrosine phosphorylation of NR2B affects the binding of the proteins to the subunit.

NMDA-initiated ERK1/2 activation is calcium-dependent because the activation of Ras by RasGRF1 occurs only if it binds calcium/calmodulin (Farnsworth et al., 1995). Additionally, the NMDA receptor requires binding of both coagonists glutamate and glycine and depolarization of the membrane to relieve voltage-dependent block by extracellular $\mathrm{Mg}^{2+}$. Altered phosphorylation of NMDAR is known to produce changes in amplitude and kinetics mediated by endogenous PKC (Lu et al., 1999), whereas PKA also can enhance NMDAR function (Westphal et al., 1999; Bird et al., 
2005; Skeberdis et al., 2006). Although heme replacement caused a complete recovery of NMDA receptors expression, measurements of total NMDA-evoked current were not restored by exogenous heme, suggesting that additional modulation or receptor trafficking are involved. However, the $\mathrm{Ca}^{2+}$ influx through NMDAR was entirely reestablished by exogenous heme. NR2B has a major role in regulation of $\mathrm{Ca}^{2+}$ current through the receptor (Krapivinsky et al., 2003; Kim et al., 2005), with tyrosine phosphorylation of NR2B causing sustained elevation of neuronal $\mathrm{Ca}^{2+}$ current (Viviani et al., 2006). Because phosphorylation of NR2B at tyrosine 1336 was rescued by exogenous heme, the increased calcium permeability may explain the full recovery of the NMDAR-mediated $\mathrm{Ca}^{2+}$ signal and is consistent with these receptors being tightly coupled to ERK1/2 activation. Our experiments with the NMDAR antagonist AP-5 and the NR2B subunit-selective antagonist ifenprodil provide additional support to this hypothesis, because inhibition of NR2B-containing receptors blocked the rescue effect of heme on ERK1/2. Another way to suppress NMDAR activation is by inhibition of SFKs, which act as a "molecular control hub" for NMDARs (Salter and Kalia, 2004), with SFK-dependent tyrosine phosphorylation increasing NMDAR channel gating (Wang and Salter, 1994) and preventing NMDAR complex degradation (Bi et al., 2000). Consistent with this, inhibition of SFKs also blocked the rescue effect of heme.

The recent evidence for spontaneous formation of the stable hemin-Slo1 BK channel (Tang et al., 2003) suggests new functions for heme as a direct modulator of ion channels. It is conceivable that heme is required for an efficient NMDAR complex assembly/stability. The increase of sodium current through voltage-gated sodium channels at the initial stage of heme deficiency may be associated with early compensation, which failed on the progress of neurite loss. However, the electrophysiological data also suggested that heme replacement caused very significant increases in sodium. It is currently unclear whether this is attributable to a direct effect of heme signaling or secondary to NMDAR signaling, and additional experiments are required.

Together, these findings lead to the conclusion that the major neuronal injury caused by heme deficiency is focused around NMDAR dysfunction. Compromised heme metabolism may be the starting point for a vicious circle: dysfunctional NMDARs lead to decreased $\mathrm{Ca}^{2+}$ influx, triggering diminished ERK1/2 activation, followed by loss of connectivity of neuronal processes and causing loss of synaptic NMDARs, further decreased $\mathrm{Ca}^{2+}$ influx, etc. This study suggests a new scenario of neurodegeneration, in which compromised heme availability produces a subtle deficit in NMDAR-dependent ERK1/2 activation leading to neurite loss rather than somatic death. Additional exploration of the molecular and cellular mechanisms of heme biology may provide broad insights into the early stages of neurodegenerative disease and age-related neurodegeneration.

\section{References}

Atamna H, Boyle K (2006) Amyloid-beta peptide binds with heme to form a peroxidase: relationship to the cytopathologies of Alzheimer's disease. Proc Natl Acad Sci USA 103:3381-3386.

Atamna H, Killilea DW, Killilea AN, Ames BN (2002) Heme deficiency may be a factor in the mitochondrial and neuronal decay of aging. Proc Natl Acad Sci USA 99:14807-14812.

Bading H, Greenberg ME (1991) Stimulation of protein tyrosine phosphorylation by NMDA receptor activation. Science 253:912-914.

Bi R, Rong Y, Bernard A, Khrestchatisky M, Baudry M (2000) Src-mediated tyrosine phosphorylation of NR2 subunits of $N$-methyl-D-aspartate receptors protects from calpain-mediated truncation of their C-terminal domains. J Biol Chem 275:26477-26483.
Bird GC, Lash LL, Han JS, Zou X, Willis WD, Neugebauer V (2005) Protein kinase A-dependent enhanced NMDA receptor function in pain-related synaptic plasticity in rat amygdala neurones. J Physiol (Lond) 564:907-921.

Bitar MS, Shapiro BH (1987) Aberration of heme and hemoprotein in aged female rats. Mech Ageing Dev 38:189-197.

Boulechfar S, Lamoril J, Montagutelli X, Guenet JL, Deybach JC, Nordmann Y, Dailey H, Grandchamp B, de Verneuil H (1993) Ferrochelatase structural mutant (FechmlPas) in the house mouse. Genomics 16:645-648.

Chernova T, Nicotera P, Smith AG (2006) Heme deficiency is associated with senescence and causes suppression of $\mathrm{N}$-methyl-D-aspartate receptor subunits expression in primary cortical neurons. Mol Pharmacol 69:697-705.

Cull-Candy S, Brickley S, Farrant M (2001) NMDA receptor subunits: diversity, development and disease. Curr Opin Neurobiol 11:327-335.

Davies R, Schuurman A, Barker CR, Clothier B, Chernova T, Higginson FM, Judah DJ, Dinsdale D, Edwards RE, Greaves P, Gant TW, Smith AG (2005) Hepatic gene expression in protoporphyic Fech mice is associated with cholestatic injury but not a marked depletion of the heme regulatory pool. Am J Pathol 166:1041-1053.

Dingledine R, Borges K, Bowie D, Traynelis SF (1999) The glutamate receptor ion channels. Pharmacol Rev 51:7-61.

Dioum EM, Rutter J, Tuckerman JR, Gonzalez G, Gilles-Gonzalez MA, McKnight SL (2002) NPAS2: a gas-responsive transcription factor. Science 298:2385-2387.

Dwivedi Y, Rizavi HS, Conley RR, Pandey GN (2006) ERK MAP kinase signaling in post-mortem brain of suicide subjects: differential regulation of upstream Raf kinases Raf-1 and B-Raf. Mol Psychiatry 11:86-98.

English JD, Sweatt JD (1996) Activation of p42 mitogen-activated protein kinase in hippocampal long term potentiation. J Biol Chem 271:24329-24332.

Faller M, Matsunaga M, Yin S, Loo JA, Guo F (2007) Heme is involved in microRNA processing. Nat Struct Mol Biol 14:23-29.

Farnsworth CL, Freshney NW, Rosen LB, Ghosh A, Greenberg ME, Feig LA (1995) Calcium activation of Ras mediated by neuronal exchange factor Ras-GRF. Nature 376:524-527.

Fiala JC, Spacek J, Harris KM (2002) Dendritic spine pathology: cause or consequence of neurological disorders? Brain Res Brain Res Rev 39:29-54.

Ghosh K, Thompson AM, Goldbeck RA, Shi X, Whitman S, Oh E, Zhiwu Z, Vulpe C, Holman TR (2005) Spectroscopic and biochemical characterization of heme binding to yeast Daplp and mouse PGRMC1p. Biochemistry 44:16729-16736.

Granick S, Sinclair P, Sassa S, Grieninger G (1975) Effects by heme, insulin, and serum albumin on heme and protein synthesis in chick embryo liver cells cultured in a chemically defined medium, and a spectrofluorometric assay for porphyrin composition. J Biol Chem 250:9215-9225.

Grynkiewicz G, Poenie M, Tsien RY (1985) A new generation of Ca2+ indicators with greatly improved fluorescence properties. J Biol Chem 260: $3440-3450$

Hardingham GE, Fukunaga Y, Bading H (2002) Extrasynaptic NMDARs oppose synaptic NMDARs by triggering CREB shut-off and cell death pathways. Nat Neurosci 5:405-414.

Ishii DN, Maniatis GM (1978) Haemin promotes rapid neurite outgrowth in cultured mouse neuroblastoma cells. Nature 274:372-374.

Jover R, Hoffmann F, Scheffler-Koch V, Lindberg RL (2000) Limited heme synthesis in porphobilinogen deaminase-deficient mice impairs transcriptional activation of specific cytochrome $\mathrm{P} 450$ genes by phenobarbital. Eur J Biochem 267:7128-7137.

Kaasik K, Lee CC (2004) Reciprocal regulation of haem biosynthesis and the circadian clock in mammals. Nature 430:467-471.

Kim MJ, Dunah AW, Wang YT, Sheng M (2005) Differential roles of NR2Aand NR2B-containing NMDA receptors in Ras-ERK signaling and AMPA receptor trafficking. Neuron 46:745-760.

Krapivinsky G, Krapivinsky L, Manasian Y, Ivanov A, Tyzio R, Pellegrino C, Ben-Ari Y, Clapham DE, Medina I (2003) The NMDA receptor is coupled to the ERK pathway by a direct interaction between NR2B and RasGRF1. Neuron 40:775-784.

Lipton SA, Nakanishi N (1999) Shakespeare in love-with NMDA receptors? Nat Med 5:270-271.

Liu J, Ames BN (2005) Reducing mitochondrial decay with mitochondrial 
nutrients to delay and treat cognitive dysfunction, Alzheimer's disease, and Parkinson's disease. Nutr Neurosci 8:67-89.

Lu WY, Xiong ZG, Lei S, Orser BA, Dudek E, Browning MD, MacDonald JF (1999) G-protein-coupled receptors act via protein kinase C and Src to regulate NMDA receptors. Nat Neurosci 2:331-338.

MacInnis BL, Campenot RB (2005) Regulation of Wallerian degeneration and nerve growth factor withdrawal-induced pruning of axons of sympathetic neurons by the proteasome and the MEK/Erk pathway. Mol Cell Neurosci 28:430-439.

Mercer K, Chiloeches A, Huser M, Kiernan M, Marais R, Pritchard C (2002) ERK signalling and oncogene transformation are not impaired in cells lacking A-Raf. Oncogene 21:347-355.

Meyer RP, Lindberg RL, Hoffmann F, Meyer UA (2005) Cytosolic persistence of mouse brain CYP1A1 in chronic heme deficiency. Biol Chem 386:1157-1164.

Moelling K, Schad K, Bosse M, Zimmermann S, Schweneker M (2002) Regulation of Raf-Akt Cross-talk. J Biol Chem 277:31099-31106.

Moon IS, Apperson ML, Kennedy MB (1994) The major tyrosinephosphorylated protein in the postsynaptic density fraction is $\mathrm{N}$-methylD-aspartate receptor subunit 2B. Proc Natl Acad Sci USA 91:3954-3958.

Ogawa K, Sun J, Taketani S, Nakajima O, Nishitani C, Sassa S, Hayashi N, Yamamoto M, Shibahara S, Fujita H, Igarashi K (2001) Heme mediates derepression of Maf recognition element through direct binding to transcription repressor Bach1. EMBO J 20:2835-2843.

Padmanaban G, Venkateswar V, Rangarajan PN (1989) Haem as a multifunctional regulator. Trends Biochem Sci 14:492-496.

Perry G, Nunomura A, Raina AK, Aliev G, Siedlak SL, Harris PL, Casadesus G, Petersen RB, Bligh-Glover W, Balraj E, Petot GJ, Smith MA (2003) A metabolic basis for Alzheimer disease. Neurochem Res 28:1549-1552.

Saba-El-Leil MK, Vella FD, Vernay B, Voisin L, Chen L, Labrecque N, Ang SL, Meloche S (2003) An essential function of the mitogen-activated protein kinase Erk2 in mouse trophoblast development. EMBO Rep 4:964-968.

Sala C, Rudolph-Correia S, Sheng M (2000) Developmentally regulated NMDA receptor-dependent dephosphorylation of cAMP response element-binding protein (CREB) in hippocampal neurons. J Neurosci 20:3529-3536.

Salter MW, Kalia LV (2004) Src kinases: a hub for NMDA receptor regulation. Nat Rev Neurosci 5:317-328.

Sangerman J, Killilea A, Chronister R, Pappolla M, Goodman SR (2001) Alpha-spectrins are major ubiquitinated proteins in rat hippocampal neurons and components of ubiquitinated inclusions in neurodegenerative disorders. Brain Res Bull 54:405-411.

Sassa S, Nagai T (1996) The role of heme in gene expression. Int J Hematol 63:167-178.

Schipper HM (2000) Heme oxygenase-1: role in brain aging and neurodegeneration. Exp Gerontol 35:821-830.

Schneggenburger R, Zhou Z, Konnerth A, Neher E (1993) Fractional contribution of calcium to the cation current through glutamate receptor channels. Neuron 11:133-143.

Sengupta A, Hon T, Zhang L (2005) Heme deficiency suppresses the expression of key neuronal genes and causes neuronal cell death. Brain Res Mol Brain Res 137:23-30.

Shedlofsky SI, Sinclair PR, Bonkovsky HL, Healey JF, Swim AT, Robinson JM (1987) Haem synthesis from exogenous 5-aminolaevulinate in cultured chick-embryo hepatocytes. Effects of inducers of cytochromes P-450. Biochem J 248:229-236.
Skeberdis VA, Chevaleyre V, Lau CG, Goldberg JH, Pettit DL, Suadicani SO, Lin Y, Bennett MV, Yuste R, Castillo PE, Zukin RS (2006) Protein kinase A regulates calcium permeability of NMDA receptors. Nat Neurosci 9:501-510.

Subramaniam S, Unsicker K (2006) Extracellular signal-regulated kinase as an inducer of non-apoptotic neuronal death. Neuroscience 138:1055-1065.

Subramaniam S, Shahani N, Strelau J, Laliberte C, Brandt R, Kaplan D, Unsicker K (2005) Insulin-like growth factor 1 inhibits extracellular signalregulated kinase to promote neuronal survival via the phosphatidylinositol 3-kinase/protein kinase A/c-Raf pathway. J Neurosci 25:2838-2852.

Sweatt JD (2001) The neuronal MAP kinase cascade: a biochemical signal integration system subserving synaptic plasticity and memory. J Neurochem 76:1-10.

Sweatt JD (2004) Mitogen-activated protein kinases in synaptic plasticity and memory. Curr Opin Neurobiol 14:311-317.

Taketani S, Immenschuh S, Go S, Sinclair PR, Stockert RJ, Liem HH, Muller Eberhard U (1998) Hemopexin from four species inhibits the association of heme with cultured hepatoma cells or primary rat hepatocytes exhibiting a small number of species specific hemopexin receptors. Hepatology 27:808-814.

Tang XD, Xu R, Reynolds MF, Garcia ML, Heinemann SH, Hoshi T (2003) Haem can bind to and inhibit mammalian calcium-dependent Slo1 BK channels. Nature 425:531-535.

Tashiro A, Sandler VM, Toni N, Zhao C, Gage FH (2006) NMDA-receptormediated, cell-specific integration of new neurons in adult dentate gyrus. Nature 442:929-933.

Tingley WG, Roche KW, Thompson AK, Huganir RL (1993) Regulation of NMDA receptor phosphorylation by alternative splicing of the C-terminal domain. Nature 364:70-73.

Tingley WG, Ehlers MD, Kameyama K, Doherty C, Ptak JB, Riley CT, Huganir RL (1997) Characterization of protein kinase A and protein kinase C phosphorylation of the $\mathrm{N}$-methyl-D-aspartate receptor NR1 subunit using phosphorylation site-specific antibodies. J Biol Chem 272:5157-5166.

Tschudy DP, Hess RA, Frykholm BC (1981) Inhibition of deltaaminolevulinic acid dehydrase by 4,6-dioxoheptanoic acid. J Biol Chem 256:9915-9923.

Tutois S, Montagutelli X, Da Silva V, Jouault H, Rouyer-Fessard P, LeroyViard K, Guenet JL, Nordmann Y, Beuzard Y, Deybach JC (1991) Erythropoietic protoporphyria in the house mouse. A recessive inherited ferrochelatase deficiency with anemia, photosensitivity, and liver disease. J Clin Invest 88:1730-1736.

Viviani B, Gardoni F, Bartesaghi S, Corsini E, Facchi A, Galli CL, Di Luca M, Marinovich M (2006) Interleukin-1beta released by gp 120 drives neural death through tyrosine phosphorylation and trafficking of NMDA receptors. J Biol Chem 281:30212-30222.

Wang YT, Salter MW (1994) Regulation of NMDA receptors by tyrosine kinases and phosphatases. Nature 369:233-235.

Westphal RS, Tavalin SJ, Lin JW, Alto NM, Fraser ID, Langeberg LK, Sheng M, Scott JD (1999) Regulation of NMDA receptors by an associated phosphatase-kinase signaling complex. Science 285:93-96.

Williams K (1993) Ifenprodil discriminates subtypes of the N-methyl-Daspartate receptor: selectivity and mechanisms at recombinant heteromeric receptors. Mol Pharmacol 44:851-859.

Zhu YHT, Ye W, Zhang L (2002) Heme deficiency interferes with the Rasmitogen-activated protein kinase signaling pathway and expression of a subset of neuronal genes. Cell Growth Differ 13:431-439. 